\title{
Pork Supply, Marketing and Challenges in Ethiopia
}

\author{
G. S. Zemelak (Corresponding author) \\ Ethiopian Institute of Agricultural Research at DZARC \\ P.O.Box 32, Debrezeit, Ethiopia \\ E-mail: zemelaks@yahoo.com \\ T. Ermias \\ Meda Welabu University \\ P.O.Box 247, Bale-Robe, Ethiopia \\ F. Tewodros \\ Ethiopian Institute of Agricultural Research at DZARC \\ P.O.Box 32, Debrezeit, Ethiopia \\ J. M. M. L. Gustavo \\ Embrapa Swine and Poultry \\ P.O.Box 21, Concordia SC, 89700-000, Concordia, Brazil
}

\begin{abstract}
Received: September 13, 2018 Accepted: Sep. 29, 2018 Published: November 13, 2018
doi:10.5296/jfi.v2i1.13647ＵRL: http://dx.doi.org/10.5296/ jfi.v2i1.13647
\end{abstract}

\begin{abstract}
The study was conducted to characterize pork and pork products marketing and challenges in Ethiopia. Multistage random sampling procedure was applied to select a total of 40 pork retailers from six towns. Structured questionnaire was used to collect information through face to face interview. Pork retailers were clustered into three categories as small scale (sell $<5 \mathrm{~kg}$ pork per day), medium scale (sell $5-10 \mathrm{~kg}$ pork per day) and large scale (sell $>10 \mathrm{~kg}$ pork per day) based on quantities of pork selling per day. Collected data were analyzed using appropriate statistical procedures of SAS and SPSS software packages. The result showed that the quantity of pork products sold per day was too small. About $61.5,15.4$ and $23.1 \%$ of
\end{abstract}




\section{MInstitute ${ }^{\text {Mink }}$}

pork retailers were selling $<5,5-10$ and $>1 \mathrm{~kg}$ of pork products per day in small, medium and large scale retailers, respectively. In most cases, pork was sold in the form of mortadella, sausage and salami. In addition to pork selling, almost all of the pork retailers were selling one or more other meat types such as beef, mutton, goat meat, fish and chicken. About $92.3 \%$ of the pork retailers were selling both beef and chicken meat, and 79.5, 48.7 and $10.3 \%$ of them were selling fish, mutton, and goat meat, respectively. The average price (followed by SE) of a kilo gram of pork was 162(6.3), 164(4.0) and 172(6.0) Ethiopian Birr (ranging 7.5 to 8 USD per kg of pork) in small, medium and large scale pork retailers, respectively. The presence of few pork consumers, lack of formal central markets and public complain against pork consumption were the major challenges observed in pig and pork marketing value chain. In concussion, the findings of this study will improve awareness on existing pork marketing systems in Ethiopia and provide valuable information that can support future interventions aiming to solve key challenges in the market value chain.

Keywords: marketed meat types, source of pork, pork products, pork marketing, challenges

\section{Introduction}

Pig production is one of the most potential livestock sub-sector that can contribute to the food security and income generation at smallholder farmer level in Africa (Abdu and Gashaw, 2010; Moreki and Mphinyane, 2011; Muhanguzi et al., 2012; Chenais et al., 2015). Unlike in other African countries, pig production in Ethiopia is emerging as a new business recently. The average number of pigs per farm ranges from 19 to 804 pigs (Goraga et al., 2016a) and most of the pigs kept by Ethiopian farmers are crossbred of different breed origin (Goraga et al., 2017c). The main reason for keeping pigs in Ethiopia is to earn money from the sale of live pigs (Goraga et al., 2017b).

Pork is the main product of pigs and serves as a source of protein for consumers. According to Goraga et al. (2017a), consumers' pork consumption behavior in Ethiopia is affected by several factors among which religion, age, marketing and income variables are the major ones. The same author reported that, pork is mainly consumed by youth and adult age groups and consumption is not affected by gender in the country. In terms of religion, Protestant and Catholics, and in terms of nationality, Asians and Europeans are the major pork consumers in the country. Pork is mostly consumed by people who have better income. Among the different pork quality traits, leanness and freshness are the two mostly preferred traits in the country; whereas, little attention is given to pork color, packing style and tenderness. In most cases, pork consumers are motivated to consume pork purposely to get fat.

Market is one of the primary factors that can ensure sustainable pork production in the country. Knowledge on the demand and supply of pork and its products, and constraints in the value chain is very important for making market decisions. Pork marketing in Ethiopia has not been well developed. This is mainly due to socio-cultural reasons. Most of Ethiopians are either Orthodox or Muslim religion followers where pork is not allowed to eat. However, the situation in Ethiopia is being changed nowadays, where pork products started getting market attention. This is mainly due to an ever increasing human population, several tourists and other foreigners who come to Ethiopia for visits or for investment or other business 
activities. Pork is becoming a favorable meat also for some Ethiopian Diasporas with foreign experiences. This emerging interest for pork consumption encouraged several producers to be engaged in pork production and marketing business in Ethiopia (Goraga et.al. 2017b). However, research and development interventions to improve pork marketing systems in Ethiopia are still lagging behind. There is limited information describing Ethiopian pork marketing and constraints in the value chain. The so far studies conducted in swine sector in Ethiopia focused mainly on characterization of swine production and mainly health aspects (Tekle et al., 2013; Tomass et al., 2013; Kumsa and Kifle, 2014; Mekuriaw and Asmare, 2014; Gebremedhin et al., 2015).

Therefore, this study was conducted to assess pork and pork products marketing systems and constraints in major towns with pork marketing potential in Ethiopia. The study was conducted in collaboration with the Brazilian Agricultural Research Corporation (EMBRAPA Poultry and Swine, Concordia, Brazil).

\section{Materials and Methods}

\subsection{Description of the Study Areas}

The study was conducted in six major towns: Bishoftu or Debre-Zeit $\left(11^{\circ} 48^{\prime} \mathrm{N} ; 38^{\circ} 30^{\prime} \mathrm{E}\right)$, Adama or Nazareth $\left(08^{\circ} 32^{\prime} \mathrm{N}\right.$; $\left.39^{\circ} 22^{\prime} \mathrm{E}\right)$, Addis Ababa $\left(09^{\circ} 02^{\prime} \mathrm{N}\right.$; $\left.38^{\circ} 42^{\prime} \mathrm{E}\right)$, Bahir Dar $\left(11^{\circ} 37^{\prime} \mathrm{N} ; 37^{\circ} 10^{\prime} \mathrm{E}\right)$, Gondar $\left(12^{\circ} 39^{\prime} \mathrm{N} ; 37^{\circ} 30^{\prime} \mathrm{E}\right)$ and Mekele $\left(13^{\circ} 33^{\prime} \mathrm{N} ; 39^{\circ} 30^{\prime} \mathrm{E}\right)$, where pork products were mainly available for sell. The five locations were far from the capital city of Ethiopia (Addis Ababa) by 45 to $729 \mathrm{~km}$. The altitude of the study locations ranges 1700 to 2300 m.a.s.l. and their average annual rainfall and temperature ranged from 549-1420 mm and $12-45^{\circ} \mathrm{C}$, respectively. Urban and peri-urban agriculture was well practiced in all of the six locations.

\subsection{Sampling Techniques and Data Collection}

The data used in this study were collected in the year 2015 to 2017 G.C. To select the study areas with pork marketing potentials, first a preliminary assessment was conducted in eleven towns in Ethiopia. Then, six towns with major pork marketing were selected for the study. Using multistage random sampling method, 24, 6 and 9 retailers a total 40 retailers (supermarkets) were selected from small, medium and large scale suppliers, respectively for data collection. Based on availability of large number of pork retailers, 30.3, 24.2, 16.7, 15.2, 9.1 and 4.5\% supermarkets were selected from Addis Ababa, Bishoftu (Debre-Zeit), Adama (Nazareth), Bahir Dar, Mekele and Gondar, respectively Pre-tested questionnaire was used for face to face interview to collect qualitative and quantitative data such as type of meat for sell (pork, beef, mutton, chicken, fish and goat meat), type of pork products (Mortadella, Salam, Sausage, Raw cut), source of pork and products pork marketing and constraints of pork products marketing. The data were collected within and around the six study locations using well trained enumerators and agricultural experts.

\subsection{Data Analysis}

The collected survey data were coded and stored in computer database for analysis using 


\section{Macrothink

SPSS (2011) version 20.0 and SAS (2002) version 9.0 software packages. Based on their quantities of pork products they could sell per day, the retailers were categorized into small scale (who could sell $<5 \mathrm{~kg}$ pork products/day), medium scale (who could sell 5-10 $\mathrm{kg}$ pork products/day) and large scale (who could sell $>10 \mathrm{~kg}$ pork products /day) sellers. Continuous data were analyzed using generalized linear model (GLM) procedures of SAS. Descriptive statistics cross-tabulation procedures of SPSS software packages were performed to see whether there were significant differences existed between the retailer categories. Ranked variable means and standard errors were analyzed using Proc means of SAS software packages. The significant differences between ranked means across the retailers were performed using a non-parametric Proc NPAR1WAY Wilcoxon of Kruskal Wallis test. An $\alpha$-level of 0.05 was used to reject the null hypothesis of the three retailer categories.

\section{Results and Discussion}

\subsection{Pork vs. Other Meat Types Marketing}

The study revealed that almost all of the pork retailers were selling one or more other meat types with pork (Table 1). There was no supermarket selling pork solely. Overall, 92.3, 92.3, $79.5,48.7$ and $10.3 \%$ of the retailers were also selling beef, chicken, fish, mutton, and goat meat (choven), respectively. Across the suppliers, pork, beef and chicken were the three top sold meat types. Except choven selling, other meat types selling showed significant differences across the three scales pork suppliers. This was due to the number of retailers supplying goat meat were nearly similar across the retailers categories. Pork and chicken selling showed highly significant $(\mathrm{P}<0.001)$ between the pork suppliers. As a whole most of the retailers were categorized under small scale meat supplier (sell less than $5 \mathrm{~kg}$ of different meat types per day). This indicates, most of the retailers were small scale meat suppliers. In North western Ethiopia, pigs are sold for external markets as pork is not consumed by local community (Mekuriaw \& Asmare, 2014). In western areas of Kenya pork is sold in local shops either as raw pork or as cooked pork where most of butchers $(59 \%)$ sold raw pork but $41 \%$ of them sold cooked pork (Levy et al., 2014). 
Table 1. Meat types sold by pork retailers

\begin{tabular}{llllll}
\hline \multirow{2}{*}{ Meat type } & \multicolumn{2}{l}{ Pork retailer category } & & \\
& \multicolumn{1}{l}{$\begin{array}{l}\text { Small } \\
(<\mathbf{5 k g} / \mathbf{d a y})\end{array}$} & $\begin{array}{l}\text { Medium } \\
\mathbf{( 5 - 1 0 K g / d a y )}\end{array}$ & $\begin{array}{l}\text { Large } \\
(\mathbf{1 0 K g} / \mathbf{d a y})\end{array}$ & & Potal \\
\hline Pork & $24(61.5)^{\mathrm{a}}$ & $6(15.4)^{\mathrm{c}}$ & $9(23.1)^{\mathrm{b}}$ & 39 & 0.0008 \\
Beef & $22(61.1)^{\mathrm{a}}$ & $6(16.7)^{\mathrm{c}}$ & $8(22.2)^{\mathrm{b}}$ & 36 & 0.0018 \\
Mutton & $12(63.2)^{\mathrm{a}}$ & $4(21.1)^{\mathrm{b}}$ & $3(15.7)^{\mathrm{c}}$ & 19 & 0.024 \\
choven & $2(50)$ & $2(50)$ & $0(0)$ & 4 & 0.37 \\
Chicken & $24(66.6)^{\mathrm{a}}$ & $6(16.7)^{\mathrm{b}}$ & $6(16.7)^{\mathrm{b}}$ & 36 & 0.0001 \\
Fish & $21(67.7)^{\mathrm{a}}$ & $5(16.1)^{\mathrm{b}}$ & $5(16.1)^{\mathrm{b}}$ & 31 & 0.0003 \\
\hline
\end{tabular}

Volumes of pork selling per day are represented by small, medium and large scale; Numbers outside and inside parenthesis represent the number of respondents and percentage, respectively. Values in the rows having the same superscript are not significantly different.

This study found that pork marketing was less competent as compared to beef marketing (Figure 1). Due to religion reason, most of Ethiopian Muslim and Christian religion followers didn't consume pork. In agreement, Mekuriaw and Asmare (2014) and Goraga et al. (2016a) reported that a religious taboo for pork consumption is significantly associated with pig production pork consumption in Ethiopia. This was the reason why most of the respondents (76.9\%) replied the degree of pork marketing was less competent as compared to beef. Only $23.1 \%$ of the respondents replied pork marketing was highly or equivalently competent with beef marketing. 


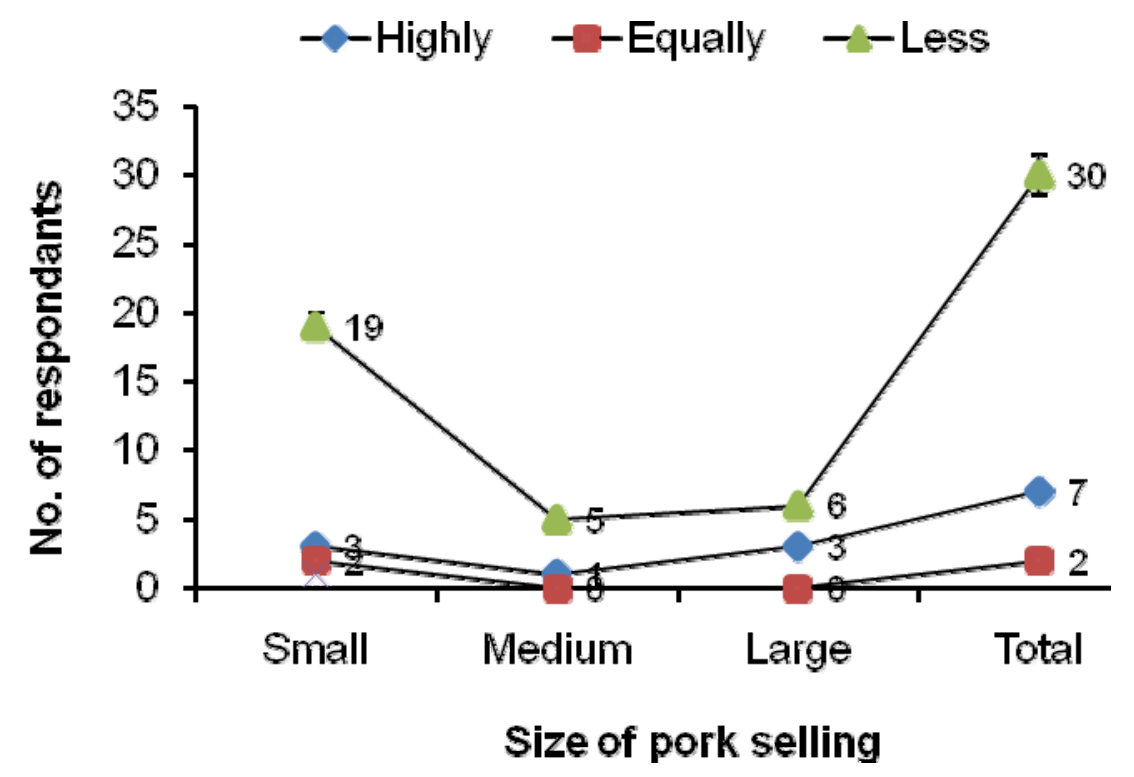

Figure 1. Degree of competency of pork marketing as compared with beef

Small, medium and large scale refers to supermarkets selling $<5 \mathrm{~kg}, 5-10 \mathrm{~kg}$ and $>10 \mathrm{~kg}$ of pork per day, respectively.

As indicated in Table 2, pork retailers ranked different types of meat in terms of volume of selling per day. There was no significant difference between retailers in the ranking of volume of meat types sold per day. Across the three scales of suppliers, beef and chicken were the first two top ranked meat types sold by pork retailers. The reason was beef price was relatively cheaper, bulkily available and preference of people to consume in Ethiopia as compared to other meat types. Pork was the fifth important meat type in terms of volume of selling in small scale suppliers but it was third important meat type in medium and large scales of suppliers. This might be medium and large scales pork suppliers provide better processed pork products in a better quality. Choven (goat meat) was the least ranked meat in terms of volume of selling per day in all pork supplier groups. This was due to less people preference of choven by communities in the study towns. Mostly choven highly preferred for consumption by people found in the eastern and in some rural areas of Ethiopia. 


\section{Macrothink}

Table 2. Ranked means (SE) of quantity of daily meat selling by pork retailers $(1=$ very high; $6=$ very low)

\begin{tabular}{lllll}
\hline \multirow{2}{*}{ Meat type } & \multicolumn{2}{l}{ Pork retailer category } & \\
\cline { 2 - 4 } & $\begin{array}{l}\text { Small } \\
(<\mathbf{5 k g} / \mathbf{d a y})\end{array}$ & $\begin{array}{l}\text { Medium } \\
\mathbf{( 5 - 1 0 K g / d a y )}\end{array}$ & $\begin{array}{l}\text { Large } \\
(>\mathbf{1 0 K g} / \mathbf{d a y})\end{array}$ & \\
\cline { 2 - 4 } Pork & $3.8(0.37)$ & $3.2(0.7)$ & $2.4(0.5)$ & 0.16 \\
Beef & $1.9(0.25)$ & $1.3(0.21)$ & $1.5(0.27)$ & 0.67 \\
Mutton & $2.7(0.45)$ & $4.3(0.48)$ & $3.7(0.33)$ & 0.09 \\
Choven & $4.3(0.67)$ & $5.5(0.50)$ & $6.0(0.20)$ & 0.20 \\
Chicken & $2.4(0.20)$ & $2.2(0.31)$ & $2.2(0.31)$ & 0.36 \\
Fish & $3.1(0.24)$ & $3.6) 0.25)$ & $3.4(0.40)$ & 0.61 \\
\hline
\end{tabular}

Small, medium and large scale refers to those supermarkets selling $<5 \mathrm{~kg}, 5-10 \mathrm{~kg}$ and $>10 \mathrm{~kg}$ of pork per day, respectively; Figures outside and inside the parenthesis represent ranked means and standard error (SE), respectively.

This study also assessed how pork marketing differs from beef market in Ethiopia. As indicated in Table 3, pork had less market as compared to beef across the retailer categories. Among retailers, $63.9 \%$ of them described pork had fewer customers, less profit and religious taboo, whereas $41.7 \%$ of the respondents said that the pork market is mainly characterized by its fewer customers. Religious taboos for pork consumption in Ethiopia, producers have fear of poor domestic marketing potential (Mekuriaw and Asmare, 2014). Religion is highly and significantly associated with pig production in Ethiopia (Goraga et al., 2016a). None of the studied features of pork marketing were significant $(\mathrm{P}>0.05)$ across the three scales of suppliers. Religious taboo for pork consumption, less profit and customers were the main reasons for less market of pork as compared to beef. This true according to Berihu and Tamir (2016) who reported that pork is consumed in Ethiopia by foreigners (tourists, investors and ambassadors). 


\section{Macrothink}

Table 3. Characteristics of pork market compared with beef

\begin{tabular}{|c|c|c|c|c|c|}
\hline \multirow[b]{2}{*}{ Characteristics } & \multicolumn{3}{|c|}{ Pork retailer category } & \multirow[b]{2}{*}{ Total } & \multirow[b]{2}{*}{ P value } \\
\hline & $\begin{array}{l}\text { Small } \\
(<5 \mathrm{~kg} / \text { day })\end{array}$ & $\begin{array}{l}\text { Medium } \\
\text { (5-10Kg/day) }\end{array}$ & $\begin{array}{l}\text { Large } \\
\text { (>10Kg/day) }\end{array}$ & & \\
\hline Less customer & $8(53.3)$ & $3(20)$ & $4(26.7)$ & 15 & 0.24 \\
\hline High customer & $4(50)$ & $1(12.5)$ & $3(37.5)$ & 8 & 0.42 \\
\hline Religious taboo & $3(75)$ & $1(25)$ & $0(0.0)$ & 4 & 0.17 \\
\hline Less customer and religious taboo & $1(50)$ & $0(0.0)$ & $1(50)$ & 2 & 0.61 \\
\hline Less profit and customer & $4(66.7)$ & $1(16.7)$ & $1(16.7)$ & 6 & 0.22 \\
\hline No difference & $1(100)$ & $0(0.0)$ & $0(0.0)$ & 1 & 0.38 \\
\hline
\end{tabular}

Figures outside and inside parenthesis represent the number of respondents and percentage, respectively; small, medium and large scale refer to supermarkets selling $<5 \mathrm{~kg}, 5-10 \mathrm{~kg}$ and $>10 \mathrm{~kg}$ of pork per day, respectively.

As shown in Table 4, pork was available for sell mainly in the form of mortadella, salami and sausage. In few cases, it was also available in the form of raw cuts. Mortadella was the top pork product mostly available followed by Salami in local supermarkets of Ethiopian towns. Raw cuts were rarely available in small and medium scales pork retailers. None of the pork products selling were significant $(\mathrm{P}>0.05)$ across the three scales of suppliers. In the western areas of Kenya, pig butcher are responsible for the coordination of activities and people necessary to transform pigs into marketable pork (Levy et al., 2014). Similar to Ethiopian pork producers and retailers, in Nigeria, pork retailers have higher market margin than the wholesalers since they processed pork into different value added products (Ajala and Adesehinwa, 2008). 
Table 4. Ranked means (SE) of forms of pork products selling (1=Mostly available product to $5=$ less available product)

\begin{tabular}{|c|c|c|c|c|}
\hline \multirow[b]{3}{*}{ Pork product } & \multicolumn{3}{|c|}{ Pork retailer category } & \multirow[b]{3}{*}{ P-valuc } \\
\hline & Small & Medium & Large & \\
\hline & $(<5 \mathrm{~kg} /$ day $)$ & $(5-10 \mathrm{Kg} / \mathrm{day})$ & $(>10 \mathrm{Kg} / \mathrm{day})$ & \\
\hline Mortadella & $1.2(0.09)$ & $1.2(0.17)$ & $1.1(0.14)$ & 0.95 \\
\hline Salami & $2.3(0.24)$ & $2.5(0.34)$ & $2.3(0.42)$ & 0.92 \\
\hline Sausage & $2.6(0.27)$ & $2.7(0.21)$ & $3.2(0.20)$ & 0.42 \\
\hline Raw cuts & $3.0(0.6)$ & $4.5(0.50)$ & $3.2(0.50)$ & 0.29 \\
\hline
\end{tabular}

Small, medium and large scale refers to those supermarkets selling $<5 \mathrm{~kg}, 5-10 \mathrm{~kg}$ and $>10 \mathrm{~kg}$ of pork per day, respectively; Figures outside and inside the parenthesis represent ranked means and standard error (SE), respectively.

\subsection{Source of Pork Supply}

Pork retailers got the pork from different sources but there was no formal central pig market. Some of the retailers got pork by slaughtering their own pigs from their farm, buying live pigs from commercial farms and slaughtering them, buying pork from other supermarkets, buying pork from processors or from one or more of the mentioned sources. As shown in Table 5, the most important source was from processors. Slaughtering those pigs obtained from commercial and own farms were also important pork sources. All the different sources of pork revealed significant difference between supplier categories. In lined with Berihu and Tamir, (2016) report five different marketing agents (pig producers, traders, supermarket owners, restaurant owners/hoteliers) are participated in pig marketing channels in Ethiopia where traders are the main suppliers of pigs to the market. Traders sold their pigs to restaurants, hotels, supermarkets and consumers. The main marketing channel was from producer-trader- supermarket-hotel/restaurant-consumer. In agreement with the current study, In Western Kenya, pigs are not sold in a central market; instead, butchers purchased pigs directly from the smallholder farmer at the farm gate (Levy et al., 2014). Unlike to Ethiopian, live pigs are sold at local village markets to intermediate traders in Nigeria (Ajala and Adesehinwa, 2008). The pig marketing channel follow a centralized pattern in which pig farmers (producers) bring pigs together in larger central and terminal markets (Ajala and Adesehinwa, 2008). The common pork marketing channels in Botswana are farm-abattoir-butchery or processing plant (wholesale) with finished products distributed to supermarkets (Montsho and Moreki, 2012). 
Table 5. Sources of pork and pork products for retailers

\begin{tabular}{|c|c|c|c|c|c|}
\hline \multirow[b]{3}{*}{ Suppliers } & \multicolumn{3}{|c|}{ Pork retailer category } & \multirow[b]{3}{*}{ Total } & \multirow[b]{3}{*}{ P value } \\
\hline & Small & Medium & Large & & \\
\hline & $(<5 \mathrm{~kg} /$ day $)$ & $(5-10 \mathrm{Kg} / \mathrm{day})$ & $(>10 \mathrm{Kg} / \mathrm{day})$ & & \\
\hline Own farm & $0(0.0)^{\mathrm{c}}$ & $1(16.7)^{b}$ & $5(83.3)^{\mathrm{a}}$ & 6 & 0.03 \\
\hline Commercial farms & $9(69.2)^{\mathrm{a}}$ & $2(15.4)^{\mathrm{b}}$ & $2(15.4)^{b}$ & 13 & 0.026 \\
\hline Supermarkets & $4(100)^{\mathrm{a}}$ & $0(0.0)^{\mathrm{b}}$ & $0(0.0)^{\mathrm{b}}$ & 4 & 0.024 \\
\hline Processors & $18(62.0)^{\mathrm{a}}$ & $5(17.2)^{b}$ & $6(20.6)^{b}$ & 29 & 0.004 \\
\hline $\begin{array}{l}\text { Commercial farm and } \\
\text { processors }\end{array}$ & $8(66.6)^{\mathrm{a}}$ & $2(16.7)^{b}$ & $2(16.7)^{b}$ & 12 & 0.049 \\
\hline
\end{tabular}

Figures outside and inside parenthesis represent the number of respondents and percentage from, respectively. Small, medium and large scale refers to those supermarkets selling $<5 \mathrm{~kg}, 5-10 \mathrm{~kg}$ and $>10 \mathrm{~kg}$ of pork per day, respectively. Values in the rows having the same superscript are not significantly different.

This study investigated the origin of pork and pork products suppliers to the supermarkets in Ethiopia (Table 6). Most of the supermarkets received pork and pork products from those pork processers found in Bishoftu (Debre-Zeit) and Addis Ababa. About 66.7\% of pork retailers received pork and pork products from pork processors found in Bishoftu (Debre-Zeit) town, the remaining $25.6 \%$ and $5.1 \%$ of them received from pork processors found in Addis Ababa city and from both sources, respectively. As indicated in Table 6, most of small scale pork retailers significantly $(\mathrm{P}<0.05)$ received pork and pork products from Bishoftu (Debre-Zeit) town as compared to medium and large scale pork retailers. 


\section{Macrothink}

Table 6. Origin of locally processed pork products

\begin{tabular}{|c|c|c|c|c|c|}
\hline \multirow{3}{*}{ Origin } & \multicolumn{3}{|c|}{ Pork retailer category } & \multirow{3}{*}{ Total } & \multirow[b]{3}{*}{ P value } \\
\hline & Small & Medium & Large & & \\
\hline & $(<5 \mathrm{~kg} /$ day $)$ & (5-10Kg/day) & $(>10 \mathrm{Kg} / \mathrm{day})$ & & \\
\hline Debre-Zeit & $15(57.7)^{\mathrm{a}}$ & $5(19.2)^{b}$ & $6(23.1)^{b}$ & 26 & 0.03 \\
\hline Addis Ababa & $6(60)$ & $1(10)$ & $3(30)$ & 10 & 0.16 \\
\hline From both & $2(100)$ & $0(0.0)$ & $0(0.0)$ & 2 & 0.14 \\
\hline
\end{tabular}

Figures outside and inside parenthesis represent the number of respondents and percentage, respectively; Small, medium and large refers to those supermarkets selling $<5 \mathrm{~kg}, 5-10 \mathrm{~kg}$ and $>10 \mathrm{~kg}$ of pork per day, respectively; Values in the rows having the same superscript are not significantly different.

\subsection{Volume of Pork Sold and the Future Plans}

As indicated in Table 7, the volume of pork and pork products sold per month in large scale pork retailers was on average 1.87 to 8.52 times higher than the volume sold in medium and small scale retailers, respectively. Volume of pork and pork products sold per month was highly significant $(\mathrm{P}<0.001)$ across the three scales of pork retailers. Overall, $77 \%$ of the pork retailers replied that volume of pork selling was less competent than beef. This was true across the three scales of pork suppliers. This was due to religious taboos of most Ethiopia communities for pork consumption. 


\section{Macrothink}

Table 7. Means (SE) of volume of pork sold (kg/month) and price (Ethiopian Birr/kg)

\begin{tabular}{|c|c|c|c|c|}
\hline \multirow[b]{2}{*}{ Description } & \multicolumn{3}{|c|}{ Pork retailer category } & \multirow[b]{2}{*}{ P-value } \\
\hline & $\begin{array}{l}\text { Small } \\
(<5 \mathrm{~kg} / \text { day })\end{array}$ & $\begin{array}{l}\text { Medium } \\
\text { (5-10Kg/day) }\end{array}$ & $\begin{array}{l}\text { Large } \\
(>10 \mathrm{Kg} / \mathrm{day})\end{array}$ & \\
\hline Volume of pork sold $(\mathrm{kg})$ & $46(7.0)^{\mathrm{c}}$ & $210(16.0)^{b}$ & $392(27.0)^{\mathrm{a}}$ & 0.0001 \\
\hline Purchasing price (Birr) & $146.2(8.9)$ & $151.8(2.8)$ & $157(2.1)$ & 0.64 \\
\hline Selling price (Birr) & $161.6(6.3)$ & $164.2(4.0)$ & $172(5.5)$ & 0.57 \\
\hline Profit (Birr) & 15.40 & 12.4 & 15 & \\
\hline
\end{tabular}

Small, medium and large scale refers to those supermarkets selling $<5 \mathrm{~kg}, 5-10 \mathrm{~kg}$ and $>10 \mathrm{~kg}$ of pork per day, respectively; Values outside and inside the parenthesis are means standard error (SE), respectively; Values in the rows having the same superscript are not significantly different.

Pork retailers could buy a kilo gram of pork in a price of ranged from 146 to 157 Ethiopian birr (Table 7). This was not significant $(\mathrm{P}>0.05)$ across the three scales of retailers. On the other hand, retailers' could sell a kilo gram of pork with a price of ranged from 162 to 172 Ethiopian Birr (7.5 to 8 USD) which was not significant $(\mathrm{P}>0.05)$ across the three scales of retailer categories. The profit was ranged from 12.4 to 15.4 Ethiopian Birr (0.6 to 0.7 USD) per kg of pork. Very far from the current finding, Berihu and Tamir (2016) reported that the current pork selling price per kg is 119.3 Ethiopian Birr in Addis Ababa city and Bishoftu town which is significantly higher than the price sold in Adama town (98.3 Ethiopian Birr). This might be true according to (Gegner, 2004), setting the price per individual pork products can be the pricing structure needs to reflect the live hog's value, as well as the processing, wrapping, curing, storage, transportation, labor, advertising, and all the other costs involved in getting your product to the consumer.

This study found that pork and pork products supplied in Ethiopian local markets showed continuity over years in an increasing trend (Table 8). All of pork retailers showed an interest to continue with the pork business (none of them decided to quit the business). Regarding the volume of pork sold, $100 \%$ of the respondents replied that they will have a plan to increase the volume of pork and pork products supply. Both the tendency to continue with the business and also to increase volume of pork and pork products supply were significant $(\mathrm{P}<0.001)$ across the three scales of retailers. This indicates, there is a room to boost pork production, demand of consumption and expand pork products marketing in Ethiopia. 


\section{IN Macrothink}

Table 8. Future marketing plans of pork and pork products retailers

Pork retailer category

\begin{tabular}{|c|c|c|c|c|c|}
\hline Parameter & $\begin{array}{l}\text { Small } \\
(<5 \mathrm{~kg} / \text { day })\end{array}$ & $\begin{array}{l}\text { Medium } \\
(5-10 \mathrm{Kg} / \text { day })\end{array}$ & $\begin{array}{l}\text { Large } \\
(>10 \mathrm{Kg} / \mathrm{day})\end{array}$ & Total & P value \\
\hline \multicolumn{6}{|c|}{ Will you continue with the business? } \\
\hline Yes & $24(63.2)^{\mathrm{a}}$ & $6(15.8)^{\mathrm{c}}$ & $8(21.1)^{b}$ & 38 & 0.0005 \\
\hline No & $0(0.0)$ & $0(0.0)$ & $0(0.0)$ & 0 & \\
\hline \multicolumn{6}{|c|}{ Volume of supply } \\
\hline Will increase & $24(63.2)^{\mathrm{a}}$ & $6(15.8)^{\mathrm{c}}$ & $8(21.1)^{b}$ & 38 & 0.0005 \\
\hline Will decrease & $0(0.0)$ & $0(0.0)$ & $0(0.0)$ & 0 & \\
\hline
\end{tabular}

Figures outside and inside parenthesis represent the number of respondents and percentage, respectively; small, medium and large scale refers supermarkets selling $<5 \mathrm{~kg}, 5-10 \mathrm{~kg}$ and $>10 \mathrm{~kg}$ of pork per day, respectively; Values in the rows having the same superscript are not significantly different.

As indicated in Table 8, almost all of the pork retailers showed an interest to continue with the business. Different opportunities motivated them to continue with the business (Table 9). The main possible motivational drivers were due to pork retailers expectations there will be enhanced awareness level public pork consumption, increment of pork demands and high expansion of urbanization in Ethiopia. None of the motivational drivers were significant $(\mathrm{P}>0.05)$ across the three scales of suppliers except profit parameter. 
Table 9. Motivational drivers for continuing on pork business

\section{Pork retailer category}

\begin{tabular}{llllll}
\cline { 2 - 4 } Motivation & $\begin{array}{l}\text { Small } \\
(<\mathbf{5 k g} / \mathbf{d a y})\end{array}$ & $\begin{array}{l}\text { Medium } \\
\mathbf{( 5 - 1 0 K g / d a y})\end{array}$ & $\begin{array}{l}\text { Large } \\
(>\mathbf{1 0 K g} / \mathbf{d a y})\end{array}$ & Total & P-value \\
\hline Profitable & $4(100)^{\mathrm{a}}$ & $0(0.0)^{\mathrm{b}}$ & $0(0.0)^{\mathrm{b}}$ & 4 & 0.02 \\
$\begin{array}{l}\text { Increase demand } \\
\text { Enhanced awareness }\end{array}$ & $5(62)$ & $2(25)$ & $1(13)$ & 8 & 0.20 \\
Urbanization & $4(50)$ & $1(13)$ & $2(22)$ & 9 & 0.09 \\
More Tourists & $3(60)$ & $0(0.0)$ & $2(40)$ & 8 & 0.42 \\
Customer satisfaction & $4(80)$ & $1(20)$ & $0(0.0)$ & 5 & 0.25 \\
\hline
\end{tabular}

Figures outside and inside parenthesis represent the number of respondents and percentage, respectively; small, medium and large scale refers supermarkets selling $<5 \mathrm{~kg}, 5-10 \mathrm{~kg}$ and $>10 \mathrm{~kg}$ of pork per day, respectively; Values in the rows having the same superscript are not significantly different.

\subsection{Market Constraints and Possible Interventions}

Different constraints influenced pork marketing in Ethiopian. The major ones were reported in Table 10. Lack of market or consumers for pork was the first ranked most important identified constraint in small and large scale retailers but public complain was the first ranked constraint in medium scale pork retailers. This might be due to taboo of pork consumption in both Christian and Muslim religion followers in Ethiopia. All the constraints were not significantly different $(\mathrm{P}>0.05)$ across the three scales of suppliers. In contrary the current finding, pig marketing constraints lack of functioning abattoir, price fluctuation, high cost of transportation, lack of price information and lack of market channel are the first five constraints ranked in Bishoftu and Adama towns while lack of market channels and functioning abattoir are the major constraints in Addis Ababa city (Berihu and Tamir, 2016). In agreement, poor market linkage is one of the constraints in north western Ethiopia (Mekuriaw and Asmare, 2014). Lack of market and government policy are the major production constraints of swine producers in Ethiopia (Goraga et al., 2016b). 
Table 10. Ranked means (SE) of constraints in pork marketing ( $1=$ very important to $12=$ least important)

\begin{tabular}{|c|c|c|c|c|}
\hline \multirow[b]{2}{*}{ Constraints } & \multicolumn{3}{|c|}{ Pork retailer category } & \multirow[b]{2}{*}{ P-value } \\
\hline & $\begin{array}{l}\text { Small } \\
(<5 \mathrm{~kg} / \text { day })\end{array}$ & $\begin{array}{l}\text { Medium } \\
\text { (5-10Kg/day) }\end{array}$ & $\begin{array}{l}\text { Large } \\
(>10 \mathrm{Kg} / \text { day })\end{array}$ & \\
\hline Less customer/market & $2.4(0.5)$ & $3.8(1.5)$ & $2.9(0.8)$ & 0.35 \\
\hline Less selling price & $8.3(0.7)$ & $7.8(1.4)$ & $8.4(1.3)$ & 0.87 \\
\hline Not profitable & $9.7(0.6)$ & $10(1.3)$ & $8.6(1.2)$ & 0.36 \\
\hline Lack of enough pork & $7.9(0.7)$ & $5.6(1.8)$ & $7.4(1.2)$ & 0.45 \\
\hline Long distance to buy pork & 7.1(0.6) & $6.7(0.7)$ & $8.0(1.6)$ & 0.48 \\
\hline Public complain & $3.8(0.7)$ & $3.7(1.0)$ & 4.1(1.4) & 0.89 \\
\hline Lack of quality pork & $5.1(0.5)$ & $8.0(1.0)$ & $4.9(0.8)$ & 0.06 \\
\hline Lack of processing tech & $4.4(0.4)$ & $3.8(0.8)$ & $4.4(0.6)$ & 0.86 \\
\hline Lack of slaughtering house & $5.4(0.4)$ & $4.5(1.2)$ & $5.5(0.7)$ & 0.65 \\
\hline Lack of shopping place & $5.2(0.5)$ & $6.0(1.0)$ & $5.7(1.0)$ & 0.78 \\
\hline Lack of favorable policy & $6.9(0.5)$ & $7.7(1.1)$ & $6.9(1.1)$ & 0.80 \\
\hline Lack of transportation & $9.5(0.7)$ & $10.8(0.6)$ & $9.8(1.8)$ & 0.68 \\
\hline
\end{tabular}

Small, medium and large scale refers to supermarkets selling $<5 \mathrm{~kg} /, 5-10 \mathrm{~kg}$ and $>10 \mathrm{~kg}$ of pork per day, respectively; Figures outside and inside the parenthesis represent ranked means and standard errors, respectively.

Pork retailers prioritized accordingly the possible intervention options to improve pork marketing in Ethiopia (Table 11). According to their view, awareness creation for pork consumption was the first suggested intervention option across the three scales of suppliers. Following this, creating market access was the second ranked suggested option in small and medium scales of suppliers. None of the possible suggested interventions were significant $(\mathrm{P}>0.05)$ across the three scales of retailers. The overall might agree with Goraga et al. (2016b) report where they stated that the better satisfaction of large scale swine producers in Ethiopia might be a better access for pork processing plants and market networking but the dissatisfaction of small and medium scale pig producers might be mainly attributed to lack of 
access for processing plants and markets to sell their live pigs.

Table 11. Ranked means (SE) of suggested interventions to improve pork marketing (1=very important to $9=$ least important)

\begin{tabular}{llllc}
\hline & \multicolumn{2}{l}{ Pork retailer category } & \\
\cline { 2 - 4 } & Small & Medium & Large & \\
Suggested solutions & $(<\mathbf{5 k g} / \mathbf{d a y})$ & $\mathbf{( 5 - 1 0 K g / d a y )}$ & $(\mathbf{1 0 K g / d a y )}$ & P-value \\
\hline Public awareness creation & $2.3(0.5)$ & $1.5(0.3)$ & $1.3(0.2)$ & 0.34 \\
Reducing buying price & $6.1(0.5)$ & $5.2(1.1)$ & $6.4(1.1)$ & 0.53 \\
Increase pork supply & $5.6(0.4)$ & $5.3(1.0)$ & $5.5(0.6)$ & 0.90 \\
Improve transportation & $5.4(0.5)$ & $6.5(0.8)$ & $6.3(0.5)$ & 0.56 \\
Avoid taboos & $4.4(0.6)$ & $4.7(1.1)$ & $4.1(1.1)$ & 0.97 \\
Improve pork quality & $5.0(0.3)$ & $5.2(1.0)$ & $4.3(0.6)$ & 0.52 \\
Improve market access & $3.7(0.5)$ & $3.8(1.0)$ & $5.5(1.0)$ & 0.26 \\
Improve health safety & $4.6(0.4)$ & $5.8(1.0)$ & $5.1(0.5)$ & 0.43 \\
Ensure favorable policy & $7.0(0.5)$ & $4.3(1.1)$ & $5.8(0.9)$ & 0.06 \\
\hline
\end{tabular}

Small, medium and large scale refers to supermarkets selling $<5 \mathrm{~kg}, 5-10 \mathrm{~kg}$ and $>10 \mathrm{~kg}$ of pork per day, respectively; Figures outside and inside the parenthesis represent ranked means and standard errors, respectively.

\section{Conclusion}

The study provided valuable information for improving pork marketing in Ethiopia. According to the findings of the study, all of the pork retailers were involved on selling one or more other meat types and most of the retailers were under small scale category. Religion taboo was the main reason that makes pork marketing was less competent as compared to other meat types. Its relatively cheaper price, bulkily available and preference of people to consume, makes beef to be consumed mostly by the community as compared to other meat types. Most of the supermarkets received pork and pork products from Bishoftu (Debre-Zeit) town. Mortadella, salami and sausage pork products were mostly available for sell but few cases raw cuts were available. The volume of pork and pork products sold per month in large scale pork retailers was by far better than sold in medium and small scale retailers. Pork and 
pork products supplied to local markets were in increasing trend over years indicating a room to increase pork production in Ethiopia. Lack of market, presence of few consumers and public complain were most important constraints for pork retailers. Therefore, awareness creation for pork consumption, creating market access and improving marketing system were the suggested intervention strategies to improve pork marketing in Ethiopia. The findings of the study will support to enhance awareness on the nutritional value of pork and its marketing in Ethiopia.

\section{Acknowledgement}

The study is part of the bilateral swine project which was conducted between the Ethiopian Institute of Agricultural Research (EIAR) and the Brazilian Agricultural Research Corporation (EMBRAPA: Swine and Poultry) using the funds provided by the Africa-Brazil Agricultural Innovation Marketplace Program. Authors would like to highly acknowledge contributors of Marketplace teams, those personnel involved in data collection and those pork retailers who provided pork marketing data.

\section{References}

Abdu, S., \& Gashaw, A. (2010). Production system dynamism and parasitic interaction of swine in and around Holetta, Ethiopia. Ethiop. Vet. J., 14, 71-81. Retrieved from https://www.ajol.info/index.php/evj/article/view/63870

Ajala, M. K., \& Adesehinwa, A. O. K. (2008). Analysis of Pig Marketing in Zango Kataf Local Government Area of Kaduna State, Nigeria. Tropicultura, 26(4), 229-239. Retrieved from http://journaldatabase.info/articles/analysis_pig_marketing_zango_kataf.html

Berihu, M., \& Tamir, B. (2016). Marketing Practices and Constraints of Pig Production under Small Scale Intensive Farming in East Shewa, Ethiopia. Global Veterinaria, 16(3), 261-267. Retrieved from https://www.idosi.org/gv/gv16(3)16/8.pdf

Chenais, E., Boqvist, S., Sternberg, L., Emanuelson, U., Ouma, E., Dione, M., ... \& Ståh, K. (2015). Knowledge, Attitudes and Practices Related to African Swine Fever Within Smallholder Pig Production in Northern Uganda. Transboundry and Emerging disease. Retrieved from https://onlinelibrary.wiley.com/doi/abs/10.1111/tbed.12347

Gebremedhin, E. Z., Kebeta, M. M., Asaye, M., Ashenafi, H., Marco, V. D., \& Vitale, M. (2015). First report on seroepidemiology of Toxoplasma gondii infection in pigs in Central Ethiopia. BMC Veterinary Research, 11, 1-9. https://doi.org/10.1186/s12917-015-0384-y

Gegner, L. (2004). Pork Marketing Alternatives. National Sustainable Agriculture Information Service. Retrieved from http://www.ngfn.org/resources/ngfn-database/knowledge/altpork.pdf

Goraga, Z. S., Tekletsadik, E., Abyi, S., Mengesha, M., \& Gustavo, L. J. M. M. (2017a). Characterization of Pork Consumers and Preference for Quality Traits in Ethiopia. World Journal of Dairy \& Food Sciences, 12(2), 79-86. Retrieved from https://idosi.org/wjdfs/wjdfs12(2)17/2.pdf 


\section{I Macrothink}

Goraga, Z., Bekele, A., Degefa, T., Alwi, M., Mengesha, M., \& Gustavo, L. J. M. M. (2017b). Live Pigs Marketing and Buyers' Characteristics in Ethiopia. ARJASR, 5(4), 244-254. Retrieved from https://www.academicresearchjournals.org/ARJASR/Abstract/2017/July/Goraga\%20et\%20al. htm

Goraga, Z., Adamu, M., Ali, S., Guteta, A., Mengesha, M., \& Gustavo, L. J. M. M. (2017c). Swine Production, Productivity and Breeding Practices in Ethiopia. Int. Inv. J. Agric. Soil Sci., $5(2)$, 26-34. Retrieved

from https://internationalinventjournals.org/journals/IIJAS/Archive/2017/July_vol-5-issue-2/Fullte $\mathrm{xt} /$ goraga $\% 20 \mathrm{et} \% 20$ al.pdf

Goraga, Z. S., Mengesha, M., Miele, M., \& Gustavo, L. J. M. M. (2016a). Swine production in Ethiopia: I. Socio-economic characteristics of producers and motivational drivers. Glob. $J$. Agri. Agri. Sci., 3(7), 279-287. Retrieved from http://www.globalscienceresearchjournals.org/gjas/964102015792

Goraga, Z., Mengesha, M., Gebregzabher, E., \& Gustavo, L. J. M. M. (2016b). Production system, feeding and slurry management of swine in Ethiopia. Glob. J. Agri. Agri. Sci., 4(1), 304-313. Retrieved form http://www.globalscienceresearchjournals.org/gjas/090820165259

Kumsa, B., \& Kifle, E. (2014). Internal parasites and health management of pigs in Burayu District, Oromia Regional State, Ethiopia. J. South African Veteri. Assoc., 85, 1-11. https://doi.org/10.4102/jsava.v85i1.913

Levy, M. A., Dewey, C. E., Poljak, Z., Weersink, A., \& Mutua, F. K. (2014). Comparing the operations and challenges of pig butchers in rural and peri-urban settings of western Kenya. African J. Agri. Res., 9(1), 125-136. https://dx.doi.org/10.5897/AJAR12.2174

Mekuriaw, Y., \& Asmare, B. (2014). Assessment of Pig Production and Constraints in Mecha District, Amhara Region, Northwestern Ethiopia. Adva. Agri., 1-5. https://doi.org/10.1155/2014/329254

Montsho, T., \& Moreki, J. C. (2012). Challenges in commercial pig production in Botswana. J. Agri. Tech. 8(4), 1161-1170. Retrieved from http://www.ijat-aatsea.com/pdf/v8_n4_12_July/2_IJAT_2012_8_4_T.pdf

Moreki, J. C., \& Mphinyane, H. G. (2011). Opportunities and challenges of pig production in Botswana. Livest. Res. Rural Dev., 23, 4. Retrieved from http://www.lrrd.org/lrrd23/4/more23087.htm

Muhanguzi, D., Lutwama, V., \& Mwiine, F. N. (2012). Factors that influence pig production in Central Uganda - Case study of Nangabo Sub-County, Wakiso district. Vet. World, 5, 346-351. https://doi.org/10.5455/vetworld.2012.346-351

SAS. (2002). SAS Online Doc ${ }^{\circledR}$, Version 9.0. SAS Institute, Inc, Cary, NC. Pp. 1176

SPSS (Statistical Procedures for Social Sciences). (2011). SPSS User's guide version 20.0. SPSS Institute Inc., Cary NC. 


\section{Macrothink}

Tekle, T., Tesfay, A., \& Kifleyohannes, T. (2013). Smallholder pig production and its constraints in Mekelle and southern zone of Tigray region, north Ethiopia. Livest. Res. Rural Dev. 25, 1-5. Retrieved from http://www.lrrd.org/lrrd25/10/tek125184.htm

Tomass, Z., Imam, E., Kifleyohannes, T., Tekle, Y., \& Weldu, K. (2013). Prevalence of gastrointestinal parasites and Cryptosporidium species in extensively managed pigs in Mekelle and urban areas of southern zone of Tigray region, Northern Ethiopia. Vet World, 6, 433-9. https://doi.org/10.5455/vetworld.2013.433-439

\section{Copyright Disclaimer}

Copyright for this article is retained by the author(s), with first publication rights granted to the journal.

This is an open-access article distributed under the terms and conditions of the Creative Commons Attribution license (http://creativecommons.org/licenses/by/4.0/). 